\begin{tabular}{|c|c|c|}
\hline 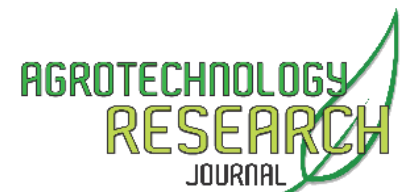 & $\begin{array}{c}\text { Agrotech Res J, June 2019, 3(1): 28-35 } \\
\text { AGROTECHNOLOGY RESEARCH } \\
\text { JOURNAL }\end{array}$ & $\begin{array}{l}\text { ISSN 2655-7924 (Print) } \\
\text { ISSN 2614-7416 (Online) } \\
\text { https://jurnal.uns.ac.id/arj } \\
\text { doi:10.20961/agrotechresj.v3i1.30382 }\end{array}$ \\
\hline
\end{tabular}

\title{
Pengaruh Pupuk Organik dan Jarak Tanam terhadap C-Organik, Populasi Jamur Tanah dan Bobot Kering Akar serta Hasil Padi Sawah pada Inceptisols Jatinangor, Sumedang
}

\author{
Ida Adviany ${ }^{1 *}$, Dick Dick Maulana ${ }^{2}$ \\ 1,2Faculty of Agriculture, Universitas Islam Nusantara, Bandung, Indonesia \\ ${ }^{*}$ Corresponding Author: \\ E-mail: idaadviany2019@gmail.com
}

Received 27 May 2019; Accepted 27 June 2019; Published 30 June 2019

\begin{abstract}
This experiment was conducted to study the effect of organic fertilizer and plant spacing on organic-C, soil fungi population, dried weight root and rice yield (Oryza sativa L.) grown on Inceptisols Jatinangor. This experiment was arranged in split plot design, consisted of two factors with 12 treatments and three replications. The first factor as main plot was organic fertilizer, which dosage of $0,200,400$ and $600 \mathrm{~kg} \mathrm{ha}^{-1}$ respectively. The second factor as sub plot was plant spacing, which of $25 \mathrm{~cm} \times 25 \mathrm{~cm}, 30 \mathrm{~cm} \times 30 \mathrm{~cm}$ and $35 \mathrm{~cm} \times 35 \mathrm{~cm}$, respectively. The result of experiment showed that there were no interaction effect between organic fertilizer and plant spacing on organic-C, soil fungi population, root dry weight and rice yields. The main effect of plant spacing treatment gave significantly effected on dried weight of root and rice yields per plot and per 10 stool. The highest rice yield per plot, $9.276 \mathrm{~kg}$ plot 1 (4.638 t ha-1) was achieved from plants with spacing $25 \mathrm{~cm} \times 25 \mathrm{~cm}$ and the highest rice yield per 10 stools was $747 \mathrm{~g}$ from plants with spacing. $35 \mathrm{~cm} \times 35 \mathrm{~cm}$
\end{abstract}

(C) 2019 Agrotechnology Research Journal

Keywords: Organic Fertilizer; Organic-C; Soil Fungi Population; Rice Yield (Oryza Sativa L.)

Cite This As: Adviany I, Maulana DD. 2019. Pengaruh Pupuk Organik dan Jarak Tanam terhadap C-Organik, Populasi Jamur Tanah dan Bobot Kering Akar serta Hasil Padi Sawah pada Inceptisols Jatinangor, Sumedang. Agrotech Res J 3(1): 27-34. https://doi.org/10.20961/agrotechresj.v3i1.30282

\section{PENDAHULUAN}

Inceptisols merupakan tanah yang belum matang (immature) dengan perkembangan profil yang lebih lemah dibandingkan dengan tanah matang dan masih banyak menyerupai sifat bahan induknya (Hardjowigeno, 2005). Penyebaran tanah Inceptisols di dunia diperkirakan sekitar $15,8 \%$ dari luas seluruh permukaan daratan (Foth 1984). Di Indonesia Inceptisols memiliki luasan sekitar 70,52 juta ha atau $44,6 \%$ dari luas daratan yang ada (Munir 1996) dan di Jawa Barat terdapat sekitar 2,119 juta ha.

Inceptisols asal Jatinangor kecamatan Jatiroke memiliki tekstur liat, bereaksi agak masam dengan $\mathrm{pH}$ $\mathrm{H}_{2} \mathrm{O}=6.2$ dan $\mathrm{pH} \mathrm{KCl}=5.1$. Kandungan $\mathrm{C}$-organik rendah (1.69\%) dan $\mathrm{N}$-total rendah $(0.14 \%)$, nisbah $\mathrm{C} / \mathrm{N}$ $=12$ menunjukkan kemudahan perombakan bahan organik oleh jasad renik tanah. Kandungan unsur hara seperti $\mathrm{K}_{2} \mathrm{O}$ total sedang $\left(26.0 \mathrm{mg} 100 \mathrm{~g}^{-1}\right)$ dan

This is an open access article

Licensed under the Creative Commons Attribution

International License CC-BY-SA 4.0 kandungan $\mathrm{P}_{2} \mathrm{O}_{5}$ rendah (15.3 $\mathrm{mg} \mathrm{kg}^{-1}$ ), hal ini diduga karena $\mathrm{pH}$ tanah yang agak masam dan tingginya kandungan liat sehingga $\mathrm{P}$ terfiksasi oleh $\mathrm{Al}$, atau Fe dan $\mathrm{Mn}$ menjadi bentuk yang tidak tersedia. Kandungan kation-kation dapat tukar seperti, $\mathrm{Ca}\left(3.7 \mathrm{cmol} \mathrm{\textrm {kg } ^ { - 1 }}\right)$ tinggi , $\mathrm{Al}\left(0.3 \mathrm{cmol} \mathrm{kg}^{-1}\right), \mathrm{Na}\left(0.1 \mathrm{cmol} \mathrm{kg}^{-1}\right), \mathrm{K}(0.3 \mathrm{cmol}$ $\left.\mathrm{kg}^{-1}\right)$ termasuk rendah. Nilai KTK $\left(21.9 \mathrm{cmol} \mathrm{kg}{ }^{-1}\right)$ termasuk sedang dan masih dapat menyangga unsurunsur hara yang hilang akibat tingkat pencucian yang tinggi.

Tanaman padi sawah (Oryza sativa L.) merupakan komoditas tanaman pangan yang sangat penting dan banyak diusahakan di Indonesia. Laju pertambahan penduduk sekitar 1,49\%, maka jumlah penduduk Indonesia diproyeksikan pada tahun 2025 akan mencapai 296 juta jiwa dan kebutuhan beras sekitar 41,5 juta ton (65,9 juta ton GKG). Disisi lain luas areal panen hanya sekitar 11-12 juta ha dan konversi lahan sawah ke pertanian lainnya atau industri terus meningkat (Simarmata 2006).

Produksi padi pada tahun 2015 mencapai 54.151 juta ton sedangkan pada tahun 2016 mencapai 54.664 juta ton atau mengalami peningkatan sebesar $0,95 \%$ 
(Deptan 2017). Upaya untuk meningkatkan produktivitas tanaman padi dengan menitikberatkan penggunaan input eksternal secara intensif memerlukan pupuk buatan yang relatif besar. Hasil berbagai kajian menunjukkan bahwa intensifikasi yang menitikberatkan pada penggunaan berbagai pupuk buatan dan pestisida mampu meningkatkan produksi dengan signifikan, tetapi memberikan dampak negatif pula terhadap lingkungan, seperti: degradasi tanah, pencemaran air dan tanah, residual pestisida, retensi hama dan penyakit, dan pada akhirnya dampak kesehatan dan keselamatan manusia yang berada dalam ekosistem pertanian tersebut. (Diver 2001).

Penggunaan pupuk $\mathrm{N}$ secara intensif akan memacu mineralisasi bahan organik tanah sehingga menyebabkan terjadinya penurunan kadar C-organik dalam tanah. Menurut Kasno et al. (2003), sebagian besar lahan sawah di Indonesia berstatus C-organik $<2 \%$. Berdasarkan indikator kesehatan tanah, maka lahan sawah dengan kadar C-organik <2\% termasuk kategori sakit. Akibatnya, walaupun dosis pupuk anorganik ditingkatkan, tetapi tidak memberikan kenaikan hasil yang signifikan. Bahkan indikasi kenaikan produktivitas padi dengan pemupukan yang intensif (bertumpu pada penggunaan pupuk buatan) sudah mencapai titik jenuh (levelling off ) dan menyebabkan terjadinya penurunan kualitas dan kesehatan tanah sawah.

Upaya untuk revitalisasi kualitas dan kesehatan tanah (soil health and quality) serta meningkatkan produktivitas tanaman padi secara berkelanjutan dapat dilakukan dengan Intensifikasi Padi Aerob Terkendali (controlled of aerobic rice intensification) Berbasis Organik (IPAT-BO), yaitu teknologi yang menitikberatkan pemanfaatan kekuatan biologis tanah, manajemen tanaman, pemupukan dan tata air secara terpadu dan terencana (by design) untuk mendukung pertumbuhan dan perkembangan sistem perakaran padi dalam kondisi aerob (Simarmata 2007b). Penggunaan pupuk organik dan pengendalian tata udara tanah agar berada dalam kondisi aerob, ternyata mampu meningkatkan keanekaragaman hayati biota tanah dan memacu pertumbuhan sistem perakaran. Peningkatan aktivitas biota tanah secara visual terlihat pada banyaknya kotoran cacing dan lubang-lubang udara (pori) pada permukaan lahan yang diberi pupuk organik dan lahan tidak tergenang (Simarmata 2007b).

Kunci keberhasilan budidaya padi dengan IPAT-BO sangat bertumpu pada keberadaan dan suplai bahan organik dalam tanah serta perluasan jarak tanam. Dengan jarak tanam lebar dan pasokan nutrisi yang baik didukung sistem tata air dan udara, padi mampu menghasilkan sekitar 80-100 anakan per rumpun (Simarmata 2007b). Jarak tanam yang biasa digunakan petani yaitu $20 \mathrm{~cm} \times 20 \mathrm{~cm}$ dan $25 \mathrm{~cm} \times 25 \mathrm{~cm}$. Hasil penelitian menunjukkan bahwa hasil tertinggi dicapai pada IR64 dengan 3 benih er lubang sebesar $7.41 \mathrm{t} \mathrm{ha}^{-1}$ pada perlakuan jarak tanam $25 \mathrm{~cm} \times 25 \mathrm{~cm}$ sedangkan dengan jarak tanam $20 \mathrm{~cm}$ x $20 \mathrm{~cm}$ menghasilkan $7.09 \mathrm{t}$ $\mathrm{ha}^{-1}$ (BPPP 1989). Pengaturan jarak tanam (jarak tanam di perlebar) dapat meningkatkan populasi mikroorganisme dalam tanah untuk meningkatkan aktivitasnya. Berdasarkan latar belakang tersebut perlu dilakukan penelitian mengenai pengaruh pupuk organik dan jarak tanam terhadap C-organik tanah, populasi jamur tanah dan bobot kering akar serta hasil padi sawah (Oryza sativa L.) pada Inceptisols Jatinangor.

\section{METODE PENELITIAN \\ Tempat dan Waktu Penelitian}

Percobaan dilakukan di lahan persawahan Kelompok Tani Jatiroke di Jatinangor, Kecamatan Jatiroke, Kabupaten Sumedang, Jawa Barat. Lokasi penelitian berada pada ketinggian sekitar $628 \mathrm{~m}$ dpl pada ordo Inceptisols, dengan tipe curah hujan B menurut Schmidt \& Fergusson. Penelitian dilakukan pada bulan April sampai September 2017.

\section{Bahan dan Alat Penelitian}

Bahan yang digunakan dalam percobaan ini adalah : lahan Inceptisols dengan luas $1913.6 \mathrm{~m}^{2}$, benih padi sawah (Oryza sativa L.) kultivar Ciherang berasal dari BBPTP (Balai Besar Penelitian Tanaman Padi) Sukamandi dengan daya kecambah $98 \%$, pupuk organik (ABG Bios), pupuk Urea $(45 \% \mathrm{~N})$, pupuk SP-36 (36\% $\left.\mathrm{P}_{2} \mathrm{O}_{5}\right)$, pupuk $\mathrm{KCl}\left(60 \% \mathrm{~K}_{2} \mathrm{O}\right)$, herbisida, pestisida dan bahan kimia untuk analisis tanah. Alat- alat yang digunakan antara lain : cangkul, alat ukur, bambu, kored, spayer, sabit, plastik, kertas label, ember, plang nama, timbangan, karung, tapi, rotary weeder, kaleng bekas biskuit dan susu, tali rapia, obor, alat tulis, alat untuk pengambilan sampel tanah (analisis parameter) dan peralatan laboratorium untuk analisis tanah dan tanaman.

\section{Rancangan Perlakuan}

Perlakuan terdiri dari 2 faktor yaitu pupuk organik dan jarak tanam yang masing- masing terdiri dari :

Faktor pertama sebagai petak utama (main plot) yaitu dosis pupuk organik $(P)$ :

$\mathrm{p}_{0}=$ tanpa pupuk organik

$\mathrm{p}_{1}=200 \mathrm{~kg} \mathrm{ha}^{-1}\left(400 \mathrm{~g} \mathrm{petak}^{-1}\right)$

$\mathrm{p}_{2}=400 \mathrm{~kg} \mathrm{ha}^{-1}\left(800 \mathrm{~g} \mathrm{petak}^{-1}\right)$

$\mathrm{p}_{3}=600 \mathrm{~kg} \mathrm{ha}^{-1}\left(1200 \mathrm{~g} \mathrm{petak}^{-1}\right)$

Faktor kedua sebagai anak petak (sub plot) yaitu jarak tanam (J) :

jo $=25 \mathrm{~cm} \times 25 \mathrm{~cm}$

$\mathrm{j}_{1}=30 \mathrm{~cm} \times 30 \mathrm{~cm}$

$\mathrm{j}_{2}=35 \mathrm{~cm} \times 35 \mathrm{~cm}$

Dari faktor perlakuan tersebut diperoleh 12 kombinasi perlakuan (Tabel I) dan masing-masing kombinasi perlakuan diulang tiga kali, sehingga seluruhnya berjumlah 36 petak.

Tabel 1. Kombinasi perlakuan antara pupuk organik dan jarak tanam

\begin{tabular}{llll}
\hline \multirow{2}{*}{ Pupuk organik (P) } & \multicolumn{3}{c}{ Jarak tanam $(\mathrm{J})$} \\
\cline { 2 - 4 } & $\mathrm{j}_{1}$ & $\mathrm{j}_{2}$ & $\mathrm{j}_{3}$ \\
\hline $\mathrm{p}_{0}$ & $\mathrm{p}_{0} \mathrm{j}_{1}$ & $\mathrm{p}_{0} \mathrm{j}_{2}$ & $\mathrm{p}_{0} \mathrm{j}_{3}$ \\
$\mathrm{p}_{1}$ & $\mathrm{p}_{1} \mathrm{j}_{1}$ & $\mathrm{p}_{1} \mathrm{j}_{2}$ & $\mathrm{p}_{1} \mathrm{~b}_{3}$ \\
$\mathrm{p}_{2}$ & $\mathrm{p}_{2} \mathrm{j}_{1}$ & $\mathrm{p}_{2} \mathrm{j}_{2}$ & $\mathrm{p}_{2} \mathrm{j}_{3}$ \\
$\mathrm{p}_{3}$ & $\mathrm{p}_{3} \mathrm{j}_{1}$ & $\mathrm{p}_{3} \mathrm{j}_{2}$ & $\mathrm{p}_{3} \mathrm{j}_{3}$ \\
\hline
\end{tabular}




\section{Rancangan Percobaan}

Rancangan percobaan yang digunakan dalam penelitian ini adalah Rancangan Petak Terbagi (Split Plot Design) untuk menguji 12 kombinasi perlakuan yang terdiri atas dua faktor. Faktor pertama terdiri dari empat taraf perlakuan dosis pupuk organik dan faktor kedua terdiri dari tiga taraf perlakuan jarak tanam. Masingmasing kombinasi perlakuan diulang tiga kali, sehingga semuanya berjumlah 36 petak percobaan. Penempatan perlakuan pada petak percobaan dilakukan secara acak.

\section{Rancangan Respons}

Pengamatan yang dilakukan terdiri atas pengamatan utama dan pengamatan penunjang. Pengamatan utama, terdiri atas :

1. C-organik ditentukan dengan metode Walkey dan Black yang dilakukan pada masa vegetatif maksimum.

2. Populasi Jamur Tanah ditentukan dengan Metode Pengenceran yang dilakukan pada masa vegetatif maksimum dan dianalisis di laboratorium mikrobiologi tanah, Jurusan IImu Tanah, Fakultas Pertanian, UNPAD.

\section{HASIL DAN PEMBAHASAN Pengamatan Penunjang}

Analisis tanah awal. Hasil analisis tanah sebelum percobaan secara lengkap disajikan pada (sifat kimia dan fisika tanah) sedangkan sifat biologi tanahnya disajikan pada Inceptisols asal Jelekong, kecamatan Baleendah memiliki tekstur liat, bereaksi agak masam dengan $\mathrm{pH}$ 6.2. Kandungan C-organik (1.69\%) dan $\mathrm{N}$ total $(0.14 \%)$ tergolong rendah. Ketersediaan $\mathrm{N}$ bagi tanaman dipengaruhi oleh beberapa faktor, antara lain oleh nisbah $\mathrm{C} / \mathrm{N}$. Dari hasil analisis, nisbah $\mathrm{C} / \mathrm{N}=12$ tergolong sedang yang menunjukkan kemudahan perombakan bahan organik oleh jasad renik tanah (Azospirillum, Azotobacter dan jamur).

\section{Tinggi Tanaman}

Pengamatan tinggi tanaman dilakukan setiap satu minggu sekali dimulai pada saat tanaman berumur 13 HST sampai tanaman berumur 69 HST. Pengamatan tinggi tanaman padi ini dilakukan dengan mengukur tanaman mulai pangkal batang sampai ujung tanaman tertinggi. Pertumbuhan yang paling tinggi yaitu pada perlakuan p3j1 (pupuk organik $600 \mathrm{~kg} \mathrm{ha}^{-1}$ dengan jarak tanam $25 \mathrm{~cm} \times 25 \mathrm{~cm}$ ) yaitu sebesar $66,37 \mathrm{~cm}$ dibandingkan dengan perlakuan tanpa pupuk organik dengan berbagai perluasan jarak tanam (p0j2 (tanpa pupuk organik dengan jarak tanam $30 \mathrm{~cm} \times 30 \mathrm{~cm}$ ) \& p0j3 (tanpa pupuk organik dengan jarak tanam $35 \mathrm{~cm} \times$ $35 \mathrm{~cm})$ ). Hal ini disebabkan karena semakin tinggi pemberian nitrogen dapat mengakibatkan bertambah panjangnya ruas (Vergara 1995). Dengan demikian pertumbuhan tinggi tanaman meningkat seiring dengan bertambahnya pemberian bahan organik sebagai sumber nutrisi bagi pertumbuhan.

Pertumbuhan tinggi tanaman padi tidak ditentukan oleh perluasan jarak tanam. Hasil pada tinggi tanaman pada perlakuan perluasan jarak tanam tanpa pupuk organik (p0j2\&p0j3) lebih rendah dari perlakuan dengan menggunakan pupuk organik tanpa perluasan jarak tanam (p1j1,p2j1\&p3j1). Hal ini berarti peranan pupuk organik lebih dominan dibandingkan dengan perlakuan perluasan jarak tanam dalam meningkatkan pertumbuhan tinggi tanaman padi.

\section{Jumlah Anakan}

Jumlah anakan yang terlihat pada perlakuan pupuk organik tanpa pupuk anorganik dengan dosis yang berbeda tanpa perluasan jarak tanam terus meningkat sampai mencapai puncaknya pada umur $61 \mathrm{HST}$ atau pada minggu ke-8 yaitu perlakuan p3j1 (pupuk organik $600 \mathrm{~kg}$ dengan jarak tanam $25 \mathrm{~cm} \times 25 \mathrm{~cm}$ ) sebanyak 36 anakan kemudian menurun sampai 32 anakan pada umur $69 \mathrm{HST}$. Hal ini disebabkan karena jarak tanam yang sempit akan meningkatkan persaingan antar tanaman maupun anakan dalam menggunakan unsur hara, air dan cahaya matahari sehingga menyebabkan anakan yang kalah bersaing akan mati sedangkan anakan yang masih bertahan disebut anakan produktif (anakan yang menghasilkan malai). Jumlah anakan pada kontrol lebih sedikit dibandingkan dengan p3j1. Hal ini disebabkan karena pupuk organik dapat memberikan pasokan nutrisi bagi perkembangan anakan.

Tanaman padi yang diberikan perlakuan perluasan jarak tanam yang berbeda tanpa perlakuan pupuk organik, jumlah anakan terbanyak dicapai pada umur 61 HST atau minggu ke-8 yaitu perlakuan p0j3 (tanpa pupuk organik dengan jarak tanam $35 \mathrm{~cm} \times 35 \mathrm{~cm}$ ) sebanyak 46 anakan dibandingkan dengan kontrol yang hanya mencapai 31 anakan. Hal ini disebabkan karena dengan menggunakan jarak tanam yang lebar dapat mengurangi persaingan $\mathrm{O}_{2}$, unsur hara, air dan pemanfaatan cahaya matahari sehingga dapat meningkatkan pertumbuhan anakan (Simarmata 2007b). Akan tetapi pertumbuhan gulmanya lebih tinggi dari perlakuan tanpa perluasan jarak tanam karena lebarnya jarak antar tanaman menyebabkan sebagian cahaya matahari langsung jatuh ke permukaan tanah diantara tanaman sehingga memudahkan pertumbuhan gulma.

Tanaman padi yang menggunakan kombinasi pupuk organik dan jarak tanam, pertumbuhan anakannya meningkat pada minggu ke-8 (61 HST) yaitu perlakuan p2j3 (pupuk organik $400 \mathrm{~kg}$ dengan jarak tanam $35 \mathrm{~cm} x$ $35 \mathrm{~cm}$ ) sebanyak 50 anakan kemudian menurun sampai 48 anakan (69 HST) dibandingkan dengan kontrol yang hanya mencapai 31 anakan. Hal ini disebabkan karena semakin tinggi dosis pupuk organik disertai dengan semakin luas zona perakaran tanaman, sehingga kemampuan akar menyerap air, dan unsur hara semakin tinggi.

\section{Gejala Serangan Hama, Penyakit dan Gulma}

Organisme pengganggu tanaman yang menyerang padi selama penelitian terdiri dari beberapa jenis serangan hama, penyakit dan gulma. Hama yang menyerang adalah hama keong, lalat padi, ulat, wereng hijau, wereng coklat, walang sangit, kepik/lembing hijau, burung dan penggerek batang padi. Seperti halnya serangan hama, serangan penyakit terjadi karena adanya migrasi dan perbedaan fase pertumbuhan di tempat percobaan dengan lingkungan sekitar, sehingga terdapat beberapa penyakit tanaman yang datang mengganggu pertumbuhan, diantaranya adalah HDJ (hawar daun jingga). 


\section{Jumlah Anakan Produktif}

Jumlah anakan produktif pada perlakuan pupuk organik dengan dosis yang berbeda tanpa perluasan jarak tanam lebih rendah jika dibandingkan dengan kontrol yaitu perlakuan p2j1 sebesar 37 anakan. Hal ini disebabkan karena pemberian pupuk dengan cara disebar menyebabkan pupuk yang digunakan hanya pada lapisan tanah bagian atas atau tidak tercampur merata ke dalam tanah sehingga akar tidak bisa menyerap pupuk yang diberikan dan mengakibatkan sebagian besar hilang karena menguap ke udara dalam bentuk $\mathrm{N}_{2} \mathrm{O}$ (nitro oksida) dan $\mathrm{N}_{2}$ (dinitrogen). Dengan demikian pemberian pupuk tidak berpengaruh nyata pada pertumbuhan anakan produktif dibandingkan kontrol. Tanaman padi yang hanya diberi perlakuan perluasan jarak tanam yang berbeda tanpa pupuk organik jumlah anakan produktifnya lebih tinggi daripada kontrol yaitu p0j3 sebesar 55 anakan. Hal ini disebabkan karena jarak tanam yang lebar akan mengurangi persaingan $\mathrm{O}_{2}$, energi matahari dan nutrisi bagi tanaman (Simarmata 2007b). Umumnya semakin lebar jarak tanam, tanaman akan memperlihatkan pertumbuhan yang lebih leluasa (Madkar et al. 2004).

Tanaman padi yang diberi kombinasi pupuk organik dan jarak tanam, jumlah anakan produktifnya lebih tinggi jika dibandingkan dengan kontrol yaitu perlakuan $\mathrm{p} 1 \mathrm{j} 3$ (pupuk organik $200 \mathrm{~kg}$ dengan jarak tanam $35 \mathrm{~cm} \times 35$ $\mathrm{cm})$ sebesar 68 anakan produktif. Hal ini disebabkan karena jarak tanam yang lebar dengan didukung pasokan nutrisi yang baik akan memudahkan dalam pengambilan air, unsur hara dan pemanfaatan cahaya bagi tanaman. Dengan demikian dapat meningkatkan jumlah anakan produktif.

Kombinasi pupuk organik dan jarak tanam mencapai jumlah anakan produktif tertinggi pada perlakuan $\mathrm{p} 1 \mathrm{j} 3$ (pupuk organik $200 \mathrm{~kg}$ dengan jarak tanam $35 \mathrm{~cm}$ x 35 $\mathrm{cm}$ ) dibandingkan dengan perlakuan pupuk organik 400 $\mathrm{kg}$ dan $600 \mathrm{~kg}$ dengan jarak tanam yang berbeda. Hal ini disebabkan karena pemberian pupuk dengan cara disebar menyebabkan tidak meratanya penggunaan pupuk organik oleh tanaman karena pupuk tidak tercampur merata ke dalam tanah yang akhirnya akar tidak dapat menyerap pupuk organik yang ditambahkan dan mengakibatkan sebagian besar hilang karena menguap ke udara dalam bentuk $\mathrm{N}_{2} \mathrm{O}$ (nitro oksida) dan $\mathrm{N}_{2}$ (dinitrogen).

\section{Pengamatan Utama}

C-organik Tanah dan Jamur Tanah. Hasil analisis statistik menunjukkan bahwa tidak terjadi pengaruh interaksi antara pupuk organik dan jarak tanam terhadap kandungan C-organik tanah dan jamur tanah. Pengaruh mandiri perlakuan pupuk organik dan jarak tanam terhadap C-organik populasi jamur tanah disajikan pada Tabel 2.

C-organik. Tabel 2 menunjukkan bahwa pemberian pupuk organik dan jarak tanam dapat meningkatkan kandungan C-organik tanah. Pupuk organik yang diberikan dapat meningkatkan kandungan $\mathrm{C}$-organik
Tabel 2. Pengaruh mandiri pupuk organik dan jarak tanam terhadap dan jamur tanah

\begin{tabular}{|c|c|c|}
\hline Perlakuan & C-Organik(\%) & $\begin{array}{l}\text { Jamur }\left(\times 10^{4}\right. \\
\text { CFU tanah-1) }\end{array}$ \\
\hline \multicolumn{3}{|l|}{$\begin{array}{l}\text { Pupuk organik (kg } \\
\mathrm{ha}^{-1} \text { ) }\end{array}$} \\
\hline $\begin{array}{l}\text { P0 : } 0 \mathrm{~kg} \mathrm{ha}^{-1} \\
\text { P1 : } 200 \mathrm{~kg} \mathrm{ha}^{-1} \\
\text { P2 : } 400 \mathrm{~kg} \mathrm{ha}^{-1} \\
\text { P3 : } 600 \mathrm{~kg} \mathrm{ha}^{-1}\end{array}$ & $\begin{array}{l}2,74 \mathrm{a} \\
2,90 \mathrm{a} \\
2,82 \mathrm{a} \\
2,80 \mathrm{a}\end{array}$ & $\begin{array}{l}12 a \\
16 a \\
18 a \\
23 a\end{array}$ \\
\hline \multicolumn{3}{|l|}{ Jarak tanam $(\mathrm{cm})$} \\
\hline $\begin{array}{l}\mathrm{J} 1: 25 \times 25 \\
\mathrm{~J} 2: 30 \times 30\end{array}$ & $\begin{array}{l}2,78 a \\
2,75 a\end{array}$ & $\begin{array}{l}17 a \\
19 a\end{array}$ \\
\hline J3 : $35 \times 35$ & $2,92 a$ & $16 a$ \\
\hline
\end{tabular}

Keterangan: Nilai rata-rata yang diikuti huruf yang sama berbeda tidak nyata menurut Uji BNT pada taraf $5 \%$.

tanah meskipun nilainya berbeda tetapi secara statistik tidak nyata. Hal ini terlihat dari peningkatan C-organik sebelum perlakuan 1,69\% menjadi 2,90\% (200 $\mathrm{kg} \mathrm{ha}^{-1}$ pupuk organik). Hal ini disebabkan karena karbon merupakan penyusun utama dari bahan organik. Semakin banyak pupuk organik yang ditambahkan ke dalam tanah, semakin banyak pula C-organik yang dilepaskan ke dalam tanah (Syukur dan Indah 2006).

Perluasan jarak tanam tidak berpengaruh terhadap kandungan $\mathrm{C}$-organik tanah. Hal ini disebabkan karena pengambilan sampel tanah hanya di daerah rizosfer sehingga jarak antar tanaman tidak berpengaruh terhadap daerah rizosfer tanaman yang satu dengan tanaman yang lain karena tergantung dari kondisi tanaman masing-masing.

\section{Populasi Jamur Tanah}

Tabel 2 menunjukkan bahwa pemberian pupuk organik dan jarak tanam tidak memberikan pengaruh nyata terhadap populasi jamur tanah, akan tetapi perlakuan pupuk organik dapat meningkatkan populasi jamur dibandingkan dengan kontrol. Hal ini terlihat dari populasi jamur awal sebesar 7. $10^{4} \mathrm{CFU} \mathrm{g}_{\text {tanah }^{-1}}$ menjadi $12.10^{4}$ CFU g tanah-1 $\left(200 \mathrm{~kg} \mathrm{ha}^{-1}\right.$ pupuk organik) dan terus meningkat seiring dengan penambahan dosis pupuk organik. Hal ini disebabkan karena kualitas dan kuantitas bahan organik yang ada dalam tanah mempunyai pengaruh langsung terhadap populasi jamur dalam tanah karena kebanyakan jamur nutrisinya heterotrofik (Subba Rao 1982).

Pupuk organik ABG Bios mempunyai C/N 20 merupakan pupuk yang menunjukkan proses mineralisasi dan immobilisasi terjadi seimbang. Adanya penurunan $\mathrm{C} / \mathrm{N}$ menunjukkan adanya penggunaan $\mathrm{C}$ sebagai sumber energi dan $\mathrm{N}$ yang diinkorporasikan sebagian digunakan untuk pembentukan sel jamur. Menurut Buckman dan Brady (1982), penambahan setiap jenis bahan organik yang dapat dirombak ke dalam tanah terutama pupuk kandang merupakan efek yang luar biasa terhadap perkembangan miselia. Akan tetapi jika kondisi tidak baik, jaringan vegetatif berkurang. Pertumbuhan jamur sangat didukung oleh faktor lingkungan tumbuh selain dari C-organik sebagai sumber energinya, jamur juga sangat membutuhkan kondisi ekologis lain seperti kandungan oksigen (aerasi), $\mathrm{pH}$, dan kelembapan tanah. Curah hujan yang rendah 
mengakibatkan kelembapan tanah menjadi rendah. Pertumbuhan jamur didukung oleh kelembapan tanah optimum karena apabila kelembapan tanah terlalu tinggi maupun rendah mengakibatkan populasi jamur menurun karena jamur bersifat aerobik (Subba Rao 1982).

Perluasan jarak tanam tidak berpengaruh terhadap populasi jamur. Hal ini disebabkan karena pengambilan sampel hanya di daerah rizosfer. Efek rizosfer sangat dipengaruhi oleh kondisi tanaman (Subba Rao 1982). Hal ini didukung oleh BPPP (1988), pertumbuhan dan perkembangan akar hanya akan terjadi secara aktif apabila kadar $\mathrm{N}$ pada batang lebih dari $1 \%$. Dengan demikian rizosfer tanaman yang satu tidak berhubungan dengan tanaman yang lain. Oleh karena itu perluasan jarak tanam tidak berpengaruh nyata terhadap efek rizosfer dalam meningkatkan populasi jamur tanah.

\section{Bobot Kering Akar}

Tidak adanya interaksi antara pupuk organik dan jarak tanam terhadap bobot kering akar. Pengaruh mandiri perlakuan pupuk organik dan jarak tanam terhadap Bobot kering akar disajikan pada Tabel 3 berikut ini:

Tabel 3. Pengaruh mandiri pupuk organik dan jarak tanam terhadap bobot kering akar

\begin{tabular}{lc}
\hline Perlakuan & $\begin{array}{c}\text { Bobot kering akar }(\mathrm{g} \\
\text { rumpun }\end{array}$ \\
\hline Pupuk organik $\left(\mathrm{kg} \mathrm{ha}^{-1}\right)$ & \\
\hline P0 : $0 \mathrm{~kg} \mathrm{ha}^{-1}$ & $27,739 \mathrm{a}$ \\
P1: $200 \mathrm{~kg} \mathrm{ha}^{-1}$ & $24,917 \mathrm{a}$ \\
P2 : 400 kg ha-1 & $26,861 \mathrm{a}$ \\
P3 : $600 \mathrm{~kg} \mathrm{ha}^{-1}$ & $26,912 \mathrm{a}$ \\
\hline Jarak tanam $(\mathrm{cm})$ & \\
J1 $: 25 \times 25$ & $20,567 \mathrm{a}$ \\
$\mathrm{J} 2: 30 \times 30$ & $28,288 \mathrm{~b}$ \\
J3 $: 35 \times 35$ & $30,967 \mathrm{~b}$ \\
\hline
\end{tabular}

Keterangan: Nilai rata-rata yang diikuti huruf yang sama berbeda tidak nyata menurut Uji BNT pada taraf 5\%.

Tabel 3 menunjukkan bahwa pupuk organik tidak berpengaruh terhadap bobot kering akar padi sawah. Hal ini disebabkan karena pemberian pupuk dengan cara disebar ke permukaan tanah mengakibatkan pupuk hanya terdapat di lapisan bagian atas atau tidak tercampur merata ke dalam tanah sehingga tidak terserap oleh perakaran tanaman yang akhirnya banyak yang menguap dalam bentuk gas yaitu $\mathrm{N}$ yang menguap ke udara dalam bentuk $\mathrm{N}_{2} \mathrm{O}$ (nitro oksida) dan $\mathrm{N}_{2}$ (dinitrogen). Menurut BPPP (1988), perkembangan akar-akar sangat dipengaruhi oleh ketersediaan $\mathrm{N}$. Pertumbuhan akar hanya terjadi secara aktif bila kadar $\mathrm{N}$ pada batang lebih dari $1 \%$. Dengan demikian perakaran yang dihasilkan lebih dangkal karena penyebarannya tidak baik (Vergara 1995).

Curah hujan yang rendah selama percobaan mengakibatkan terjadinya pemadatan tanah. Dalam keadaan memadat tanah menjadi keras, pori-pori menyempit. Dengan demikian akar akan mengalami kesukaran dalam menembus tanah (Saifuddin Sarief, 1989). Menurut Russel (1977), akar tidak bisa menembus pori-pori kurang dari diameter ujung akar itu sendiri. Buckman dan Brady (1982) menyatakan bahwa kecepatan difusi oksigen (KDO) sangatlah menentukan pertumbuhan tanaman. Pertumbuhan akar kebanyakan tanaman menurun apabila KDO turun sampai kira-kira $20 \mathrm{~g} \times 10^{-8} \mathrm{~cm}^{-2} \mathrm{menit}^{-1}$. Pertumbuhan tertinggi pada umumnya selama KDO masih di atas $30-34 \mathrm{~g} \mathrm{x} 10^{-8} \mathrm{~cm}$ ${ }^{2}$ menit ${ }^{-1}$.

Perluasan jarak tanam dapat meningkatkan bobot kering akar. Hal ini disebabkan karena semakin lebar jarak tanam semakin luas daerah perakaran. Berdasarkan kajian lapang jarak tanam minimal adalah $30 \mathrm{~cm}$ x $30 \mathrm{~cm}$ dan maksimal $50 \mathrm{~cm}$ x $50 \mathrm{~cm}$ (Simarmata, 2007b). Jarak tanam yang lebar akan meningkatkan penyerapan unsur hara dan pemanfaatan cahaya bagi tanaman, umumnya makin lebar jarak tanam tanaman akan memperlihatkan pertumbuhan yang lebih leluasa (Madkar et al. 2004).

\section{Hubungan Antara Hasil Padi Sawah dan Parameter Utama (C-Organik, Populasi Jamur Tanah dan Bobot Kering Akar)}

Hubungan antara bobot padi sawah per petak dengan C-organik ditunjukkan pada populasi jamur tanah dan bobot kering akar. Hasil uji statistik terlihat bahwa tidak terdapat hubungan yang nyata antara bobot padi sawah per petak dengan parameter utama yang dinyatakan dengan nilai keeratannya hanya 0,193 atau $19,3 \%$ sedangkan hubungan antara bobot padi sawah per 10 rumpun dengan C-organik ditunjukkan pada hubungan populasi jamur tanah dan bobot kering akar. Hasil uji statistik terlihat bahwa tidak terdapat hubungan yang nyata antara bobot padi sawah per 10 rumpun dengan parameter utama yang dinyatakan dengan nilai keeratannya hanya 0,239 atau 23,9\% sedangkan nilai keeratan yang menunjukkan adanya hubungan antara dua variabel yaitu $>50 \%$. Hal ini terlihat dari hasil statistik menunjukkan bahwa pengaruh perlakuan pupuk organik dan jarak tanam terhadap parameter utama tidak nyata meskipun nilainya berbeda (Tabel 3), tetapi hanya bobot kering akar yang peningkatannya berbeda nyata akibat perlakuan jarak tanam. Dengan demikian banyak faktor yang mempengaruhi hasil padi sawah. Salah satu faktornya yaitu lingkungan yang mengakibatkan pemadatan tanah sehingga menurunkan sifat fisik tanah dan menghambat perkembangan perakaran tanaman yang akhirnya hasil padipun menurun.

Pada parameter utama (C-organik dan bobot kering akar) berpotensi menurunkan bobot padi sawah per petak sedangkan populasi jamur tanah cenderung meningkatkan hasil padi sawah per petak. Bobot padi sawah per 10 rumpun dapat meningkat hasilnya dengan keberadaan parameter utama (C-organik, populasi jamur tanah dan bobot kering akar). Hal ini disebabkan karena perbedaan populasi tanaman tiap jarak tanam, terlihat dengan adanya peningkatan komponen hasil padi sawah yaitu anakan produktif seiring dengan perluasan jarak tanam.

\section{Hasil Padi Sawah dalam Bentuk Gabah Kering Panen (GKP)}

Hasil penelitian menunjukkan bahwa tidak adanya interaksi antara pupuk organik dan jarak tanam terhadap hasil padi sawah baik bobot gabah kering panen per petak maupun per 10 rumpun. Pengaruh mandiri perlakuan pupuk organik dan jarak tanam terhadap bobot gabah kering panen per petak terdapat pada Tabel 
3 dan bobot gabah kering panen per 10 rumpun terdapat pada Tabel 4.

Tabel 4. Pengaruh mandiri pupuk organik dan jarak tanam terhadap bobot gabah kering panen per petak

\begin{tabular}{lc}
\hline Perlakuan & $\begin{array}{c}\text { Bobot gabah kering } \\
\text { panen }(\mathrm{GKP})\left(\mathrm{t} \mathrm{ha} \mathrm{-}^{-1}\right)\end{array}$ \\
\hline Pupuk organik $\left(\mathrm{kg} \mathrm{ha}^{-1}\right)$ & \\
\hline P0 $: 0 \mathrm{~kg} \mathrm{ha}^{-1}$ & $4,141 \mathrm{a}$ \\
$\mathrm{P} 1: 200 \mathrm{~kg} \mathrm{ha}^{-1}$ & $4,047 \mathrm{a}$ \\
$\mathrm{P} 2: 400 \mathrm{~kg} \mathrm{ha}^{-1}$ & $4,419 \mathrm{a}$ \\
P3 $: 600 \mathrm{~kg} \mathrm{ha}^{-1}$ & $4,121 \mathrm{a}$ \\
\hline Jarak tanam $(\mathrm{cm})$ & \\
\hline $\mathrm{J} 1: 25 \times 25$ & $4,638 \mathrm{c}$ \\
$\mathrm{J} 2: 30 \times 30$ & $4,257 \mathrm{~b}$ \\
$\mathrm{~J} 3: 35 \times 35$ & $3,652 \mathrm{a}$ \\
\hline
\end{tabular}

Keterangan: Nilai rata-rata yang diikuti huruf yang sama berbeda tidak nyata menurut Uji BNT pada taraf $5 \%$.

Tabel 5. Pengaruh pupuk organik dan jarak tanam terhadap bobot gabah kering panen per 10 rumpun

$\begin{array}{lc}\text { Perlakuan } & \begin{array}{c}\text { Gabah kering panen per } 10 \\ \text { rumpun (g } 10 \text { rumpun }\end{array}\end{array}$

Keterangan: Nilai rata-rata yang diikuti huruf yang sama berbeda tidak nyata menurut Uji BNT pada taraf $5 \%$.

Hasil analisis statistik menunjukkan tidak terjadi interaksi antara pupuk organik dengan jarak tanam terhadap hasil padi sawah, baik bobot gabah kering panen per petak (Tabel 3) maupun per 10 rumpun (Tabel 4). Secara mandiri jarak tanam berpengaruh nyata terhadap hasil padi sawah, baik bobot gabah kering panen per petak maupun per 10 rumpun. Secara kuantitas jarak tanam yang sempit dapat meningkatkan bobot gabah kering panen per petak (Tabel 3). Hal ini disebabkan karena jarak tanam $25 \mathrm{~cm} \times 25 \mathrm{~cm}$ memiliki populasi tanaman yang lebih banyak yaitu 160000 tanaman dengan hasil padi sawah sebesar 4,638 $\mathrm{tha}^{-1}$ dibandingkan dengan jarak tanam $35 \mathrm{~cm} \times 35 \mathrm{~cm}$ dengan populasi 81633 tanaman dan hasil padi sawah sebesar 3,652 t ha-1. Pada umumnya, produksi tiap luas yang tinggi tercapai dengan populasi tinggi karena tercapainya penggunaan cahaya secara maksimal diawal pertumbuhan akan tetapi pada akhirnya, penampilan masing-masing tanaman setiap individu menurun karena persaingan untuk cahaya dan faktorfaktor tumbuh lainnya. Tanaman memberikan respon dengan mengurangi ukuran baik pada seluruh tanaman maupun bagian-bagian tanaman (Harjadi 2002).

Secara kuantitas hasil padi sawah dalam bobot kering panen per petak lebih tinggi pada jarak tanam yang sempit $(25 \mathrm{~cm} \times 25 \mathrm{~cm})$ dibandingkan dengan jarak tanam yang lebar $(35 \mathrm{~cm} \times 35 \mathrm{~cm})$ karena populasinya lebih tinggi. Akan tetapi apabila kualitas hasil padi sawah merupakan faktor penentu hasil optimum hanya terjadi pada suatu populasi tertentu (Harjadi 2002). Berdasarkan data pada Tabel 6 terdapat pengaruh jarak tanam dalam meningkatkan hasil padi sawah bobot gabah kering panen per 10 rumpun sangat nyata. Hal ini disebabkan karena semakin lebar jarak tanam, maka semakin baik pertumbuhan dan perkembangan akar serta anakan produktif yang akhirnya dapat meningkatkan hasil padi sawah. Pada jarak tanam $35 \mathrm{~cm}$ x $35 \mathrm{~cm}$ memberikan hasil tertinggi sebesar $679 \mathrm{~g} 10$ rumpun ${ }^{-1}$ dibandingkan jarak tanam yang sempit $(25 \mathrm{~cm}$ x $25 \mathrm{~cm}$ ) sebesar $417 \mathrm{~g} 10$ rumpun $^{-1}$. Hal ini disebabkan karena jarak tanam yang lebar dapat mengurangi persaingan dalam penggunaan cahaya, unsur hara dan air sehingga dapat meningkatkan hasil padi sawah yang lebih tinggi (Simarmata 2007b).

Pengamatan utama (C-organik, populasi jamur tanah dan bobot kering akar) tidak berhubungan dengan hasil padi sawah bobot gabah kering panen per petak maupun per 10 rumpun sehingga tidak dapat meningkatkan hasil padi sawah secara nyata. Akan tetapi secara statistik hanya bobot kering akar yang meningkat secara nyata seiring dengan perluasan jarak tanam. Jarak tanam 35 $\mathrm{cm} \times 35 \mathrm{~cm}$ menghasilkan 30,967 $\mathrm{g}_{\text {rumpun }^{-1}}$ dibandingkan kontrol (jarak tanam $25 \mathrm{~cm} \times 25 \mathrm{~cm}$ ) hanya 20,567 g rumpun $^{-1}$ atau mengalami peningkatan sebesar $66.416 \%$. Oleh karena itu semakin lebar jarak tanam akan meningkatkan sistem perakaran dan anakan produktif dibandingkan dengan kontrol serta penggunaan benih yang lebih ekonomis dibandingkan dengan jarak tanam yang sempit (Rabenandrasana 2002).

Perlakuan pupuk organik tidak berpengaruh nyata terhadap hasil padi sawah baik hasil bobot gabah kering panen per petak maupun per 10 rumpun. Hal ini disebabkan karena pemberian pupuk organik dengan cara disebar ke permukaan tanah mengakibatkan pupuk hanya terdapat di lapisan bagian atas atau tidak tercampur merata ke dalam tanah sehingga tidak terserap oleh perakaran tanaman yang akhirnya banyak yang menguap dalam bentuk gas yaitu $\mathrm{N}$ yang menguap ke udara dalam bentuk $\mathrm{N}_{2} \mathrm{O}$ (nitro oksida) dan $\mathrm{N}_{2}$ (dinitrogen) yang akhirnya ketersediaan bagi tanaman menjadi berkurang.

\section{KESIMPULAN}

1. Tidak terjadi interaksi antara pupuk organik dengan jarak tanam terhadap C-organik, populasi jamur tanah dan bobot kering akar serta bobot gabah kering panen per petak maupun bobot gabah kering panen per 10 rumpun. 
2. Secara mandiri pengaruh jarak tanam berbeda nyata terhadap bobot kering akar, bobot gabah kering panen per petak dan bobot gabah kering panen per 10 rumpun sedangkan pupuk organik tidak nyata pengaruhnya.

\section{DAFTAR PUSTAKA}

Aisyah D, Suyono, Kurniatin T, Mariam S, Nurlaeny N, Damayani M, Yuniarti A, Emma TNS, Machfud Y, Samusa T, Joy B. 2003. Kesuburan Tanah dan Pemupukan. Jurusan Ilmu Tanah Fakultas Pertanian. UNPAD.

Andoko A. 2005. Budidaya Padi Secara Organik. Penebar Swadaya. Jakarta.

Bostan H. 1989. Pengaruh Jarak Tanam dan Dosis Pemupukan $\mathrm{N}$ terhadap Pertumbuhan dan Hasil Tanaman Selada (Lactuca sativa L.). Tesis Pasca Sarjana Unpad. Bandung.

BPPP. 1988. Padi 1. Pusat Penelitian dan Pengembangan Tanaman Pangan. Bogor.

Buckman, Brady, 1982. Ilmu Tanah. Diterjemahkan oleh Soegiman. Bhatara karya aksara. Jakarta.

De Freites JR, Banerjee MR, Germida JJ. 1997. Phosphate-Solubilizing Rhizobacteria Anhance The Growth And Yield But Not Phosphorus Uptake Of Canola (Brassica Napus L.). Biol. Fertil. Soil. 24:358364

Deptan. 2017. Perkembangan Produksi Pertanian. http://database.deptan.go.id/bdspweb/f4-freeframe.asp (diakses tanggal 21 Maret 2017)

Diver S. 2001. Resouces Guide to Organic Sustainable Vegetable Production. www.atra.ncat.org. (diakses tanggal 02 Februari 2017).

Foth HD. 2004. Dasar-dasar IImu Tanah. Diterjemahkan oleh Purbayanti ED, Lukiwati DR, Srimulatsih. Gajah Mada University Press. Yogyakarta.

Gomez, KA, Gomez, AA 1995. Prosedur Statistik Untuk Penelitian Pertanian. Universitas Indonesia. Jakarta.

Harjowigeno S. 1985. Genesa dan Klasifikasi Tanah. Pasca Sarjana IPB. Bogor.

Harjowigeno S. 1993. Klasifikasi Tanah dan Pedogenesis. Akademika Pressindo. Jakarta.

Illmer PA, Schimer F. 1992. Solubilization Of Inorganic Phosphate By Microorganism Isolated From Forest Soils. Soil Biol. Biochem. 24(4) : 389-395.

Illmer PA, Abarto, Schimer F. 1995. Solubilizing Of Hardly Soluble $\mathrm{AlPO}_{4}$ With P-Solubilizing Microorganism. Soil Biol. Biochem. 27 (3) : 265-270.

Ingham ER. 2004. Soil Fungi. Soil Biology Primer. http://soils.usda.gov/sql/concepts/soil_Biology/fungi. html.[diakses tanggal 2 Februari 2007].

Kasno A, Setyorini D, Nurjaya. 2003. Status C-organik Lahan Sawah di Indonesia. Pros. HITI, Padang.

Ma'shum M, Soedarsono J, Susilawati LE. 2003. Biologi Tanah. CPIU Pasca IAEUP. Jakarta.
Rusdi M. 1985. Pengaruh Jarak Tanam dan Pemupukan Fosfor terhadap Pertumbuhan dan Produksi Jagung yang Ditanam Bersama dengan Centrosema pubescens. Laporan Penelitian. Fakultas Pertanian Universitas Hasanudin (tidak dipublikasikan).

Munir M. 1996. Tanah-Tanah Utama di Indonesia: Karakteristik, Kelas dan Pemanfaatan. PT. Dunia Pustaka. Jakarta.

Madkar OR, Rudiman, Kurniadie D. 2004. Respon Tanaman Bawang Merah (Allium ascalonicum) dan Pertumbuhan Gulma akibat Pemberian Berbagai Jenis dan Dosis Herbisida. Laporan Penelitian. Lembaga Penelitian Universitas Padjadjaran (tidak dipublikasikan).

Justin R. 2002. Revolusi dalam Intensifikasi Padi. Salam. 1 Desember 2002.

Richardson AE. 2002. Making Microorganisms Mobilize Soil Phosphorus. Csiro Plant Industry. Canbera. Australia.

webcd.usal.es/web/psm/abstracts/richardson2.htm48k(diakses tanggal 22 Februari 2007).

Russel EW. 1977. Soil Conditions and Plant Growth, 10th ed., Longman, London.

Saifuddin, Sarief. 1989. Kesuburan dan Pemupukan Tanah Pertanian. Pustaka Buana. Bandung.

Saifuddin, Sarief. 1986. IImu Tanah Pertanian. Pustaka Buana. Bandung.

Setiawati, R Mieke. 2004. Pupuk Biologis dari Mikroba Pelarut Fosfat http://www.pikiranrakyat.com/cetak/0304/11/cakrawala/lainnya02.htm. [diakses 13 Januari 2017].

Simarmata T. 1999. Upaya Peningkatan Kualitas Pupuk Organik. Karya Ilmiah. Fakultas Pertanian Universitas Padjadjaran. Jatinangor. (tidak dipublikasikan).

Simarmata T. 2006. Teknologi Peningkatan Padi Berbasis Organik. Gatelink. http://www.gateling.com. [diakses tanggal 10 Februari 2007].

Simarmata, T. 2007a. Pemberdayaan Kekuatan Biologis Tanah (Soil Biological Power) dalam Teknologi Peningkatan Produksi Padi Berbasis Organik Berpola SRI. Makalah Seminar Pro dan Kontra SRI. Tanggal 19 Februari 2007. UNPAD.

Simarmata T. 2007b. Berswasembada dan Menjadi Eksportir Beras-Intensifikasi padi Aerob Terkendali Berbasis Organik (IPAT) Melipatgandakan Produksi Padi. Makalah Seminar Dan Lokakarya Nasional Teknologi Intensifikasi Padi Aerob Terkendali (IPAT). Tanggal 17 Juli 2007. SPLPP Fakultas Pertanian Universitas Pajdajdaran.

Sitompul SM. , Guritno B. 1995. Analisa Pertumbuhan Tanaman. Gajah Mada University Press. Yogyakarta.

Soil Survey Staff. 1999. Soil Taxonomy USDA. Second Edition. Agr. Handbook 436. USDA-Natural Resources Conservation Service. Washington DC. 
Harjadi SS. 2002. Pengantar Agronomi . PT. Gramedia Utama. Jakarta. Hal 110-136.

Subagyo H, Suharta N, Siswanto AB. 2000. Sumberdaya Lahan Indonesia dan Pengeloaannya. Pusat Penelitian Tanah dan Agroklimat. Badan Penelitian dan Pengembangan Pertanian. Departemen Pertanian.

Rao S. 1982. Biofertilizers in Agriculture. Oxford \& IBH Publishing Co. New Delhi.

Syukur A, Indah NM. 2006. Kajian Pengaruh Pemberian Macam Pupuk Organik terhadap Pertumbuhan dan
Hasil Tanaman Jahe di Inceptisol, Karanganyar. IImu Tanah dan Lingkungan. 6 (2) p: 124-131.

Syafei. MS. 2006. Pengelolaan Sawah Bukaan Baru.http://sumbar.litbang.deptan.go.id/sing200206s y.pdf (diakses tanggal 22 Januari 2017).

Utami SNH, Handayani S. 2003. Sifat Kimia Entisol pada Sistem Pertanian Organik. Ilmu Pertanian. 10(2) : 6369.

Vergara BS. 2005. Bercocok Tanam Padi. Departemen Pertanian. Jakarta. 